\title{
Participation in Medical Tourism versus Physical Activity of Patients after Liposuction: What are the Concerns about Health and Quality of Life?
}

Authors' contribution:

A) conception and design of the study

B) acquisition of data

C) analysis and interpretation of data

D) manuscript preparation

E) obtaining funding

\section{Adrian Lubowiecki-Vikuk}

Kazimierz Wielki University in Bydgoszcz, Poland

\begin{abstract}
Nowadays, the act of taking care of one's appearance has become a marker of a healthy lifestyle among both women and (mostly metrosexual) men. Physical activity plays a minor role, and tourist trips are more and more frequently combined with the consumption of medical services, including surgery and aesthetic dermatology. The aim of this study is to explain the phenomenon of medical tourism, particularly the specialized category of medical tourism for liposuction treatments, and its relation to the values of physical culture. The work is theoretical; it is supplemented by references to the presented issues in the form of a case study of "lipotourism" and its participants. As a result, the profile of a medical tourist has been identified against which a "lipotourist" constitutes an inimitable case. It seems that although the purpose for the travels of such a tourist is recognized, it still remains a matter of conjecture in terms of experience and behavior.

To prove the thesis that participating in tourism for medical reasons can affect one's quality of life, certain conditions must be met: 1 . The applied treatment must not cause (permanent) damage to the patient's health; 2. Liposuction must be treated exclusively as an (invasive) aesthetic surgery and not as a method of weight reduction; 3. Regular physical activity and a healthy diet and lifestyle must be included in the process of body shaping, and 4. Health and physical education must be treated as superior values of quality of life. The existing considerations should only be regarded as preliminary.

body image, obesity, lipectomy, travel medicine, leisure activities
\end{abstract}

\section{Introduction}

The consumer lifestyle of contemporary society promotes tourism, translating into specific benefits for both the national economy and for changing consumption patterns. At the same time, broadly defined health services often become part of tourist trips or are their main goal. This is called health tourism, and various forms of it may be distinguished: health resort tourism (sanatorium tourism), spa and wellness tourism, and medical tourism. When considering the participants of medical tourism, it should be noted that in the domestic and international market, a new type of consumer has emerged for whom the health aspect 
alone does not always seem to be a priority. Concerns about outward appearance have become a benchmark of lifestyle. The improvement of one's figure to be in line with the currently prevailing cult of the young and slim body and the use of surgery and aesthetic dermatology constitute examples of travel motives of socalled medical tourists. The ongoing demographic, socio-cultural, economic, and technological changes should be perceived as sources of this kind of behavior. In Poland, not only ill, elderly individuals exasperated by a long waiting period to obtain guaranteed free medical services are becoming medical tourists (Kowalska et al., 2015). In recent years, there has been an increase in self-confident young tourists (both women and men) who want to improve their health, well-being, strength, vitality, and beauty. Consequently, the abovementioned behaviors and changes affect the quality of life of certain social groups.

The aim of this compilation work is to explain the phenomenon of medical tourism, describe the dynamics of its development, and attempt to identify its consequences, especially for health of those who participate in it. In this paper, the intensification of medical tourism oriented towards liposuction treatments, called lipotourism, has been described against the background of the values and elements of physical culture. In this attempt, the desk research method was implemented, which is mainly a synthetic analysis of relevant scientific publications and documents. Some cases of post-liposuction patients have been presented via the direct interview method. However, they do not constitute an essential component of the argument, but should be treated as a point of reference for the analyzed notions. It should be emphasized that this is just a contribution to broader research.

\section{Medical tourism: The phenomenon of the twenty-first century}

Although the term "medical tourism" is new, the very idea of its origins is not an unknown phenomenon. Even in ancient times, one of the goals of traveling was to improve psycho-physical forces. However, only in the first decade of the twenty-first century, mainly because of mass media (television, internet, magazines) and the tourism industry, has the medical tourism phenomenon gained momentum (Lubowiecki-Vikuk, 2012b; Lubowiecki-Vikuk, \& Rab-Przybyłowicz, 2015).

In the literature, the term "medical tourism" is occasionally used as a synonym for health resort tourism, spa tourism, and wellness tourism. According to Lubowiecki-Vikuk (2012b), such an explanatory approach of the various sciences may undoubtedly be due to the fact that only recently has empirical research in the field of this form of tourism been conducted. It should be recognized that the concept of medical tourism is still unstable.

"When reading about health and medical tourism one might think that both terms apply to the same category of tourism, based on: caring for one's health, stress relief, personal wellbeing, fitness and body attractiveness. Indeed, many times these two terms are used interchangeably. For a proper understanding of the whole subject, the distinction between health tourism and medical tourism is vital to show that both categories are not the same but yet they are related. Both trends have emerged due to changes in demographics, today's education, standard of living, social behavior, and lifestyle” (Breitrück, \& Nunn 2011, p. 57).

Medical tourism, in the broad sense, encompasses three segments: health (resort) tourism, spa tourism, and wellness tourism. In addition, medical tourism also accounts for a part of national, international, and domestic tourism. Thus, it is important to consider medical tourism not only in terms of the arrivals and departures of international tourism, but also in terms of domestic tourism, which is often overlooked in the analysis of medical tourism (Lubowiecki-Vikuk, 2012a, b). 
In the field of science and in social life (Rasińska, \& Siwiński, 2014), medical tourism is still neither fully recognized nor clearly defined. In the literature, one may come across an approach that treats the medical tourism phenomenon in the following ways:

1. As an obligatory point of the program of a tourist trip (linked to leisure tourism, including visits to friends and relatives - VFR), or;

2. As identical to the concept of global healthcare, where this phenomenon does not apply to healthcare in emergencies during a patient's stay abroad, but to the main motive of traveling abroad (medical aspect) (Lubowiecki-Vikuk, 2012b).

It is worth noting that patients, referred to as medical tourists, do not always take a strictly medical journey. Quite often they undergo medical treatment on the occasion of allegedly visiting relatives and friends (Matteelli et al., 2012; Wongkit, \& McKercher, 2013), or during a typical vacation.

Therefore, one might attempt to assume that medical tourism is:

"a conscious activity, in which a traveler (a medical tourist) aims to receive healthcare services

- in his or her own country or overseas - to preserve (or acquire) a better health condition,

and/or aesthetic appearance of his or her own body, sometimes combined with relaxation, regeneration of physical and mental strength, sightseeing and entertainment" (LubowieckiVikuk, 2010, p. 186).

This term is associated with medical travel, international patient service, cross-border (Official Journal of the European Union, 2011) travel, or global healthcare. Medical tourism can fill the gap in the healthcare system in a patient's home country, providing him with better service, faster access, and cheaper treatment abroad, as well as access to treatments that are not legally available in his place of residence (Cohen, 2012; Franzblau, \& Chung, 2013; Freyer, \& Kim, 2014). Patients' activities are also related to their dissatisfaction with their national healthcare systems (Cameron et al., 2014).

Medical tourism is conceptually full of nuances, contrasts, and contradictions which make it difficult to describe; the lack of reliable data further aggravates this situation (Reed, 2008). The very essence of medical tourism makes it possible to divide it into various categories, such as dental tourism, reproductive tourism, abortion tourism, specialized medicine tourism (including surgical tourism, bariatric tourism, and lipotourism), pharmaceutical tourism, euthanasia tourism, medical spa tourism, oncology tourism, and transplant tourism (Lubowiecki-Vikuk, 2015; Lubowiecki-Vikuk, \& Mucha, 2015). The above division is neither precise nor thorough. Some categories give rise to tensions, including those of an economic, religious, socio-cultural, and moral nature. The very phenomenon of medical tourism increasingly becomes the subject of numerous debates, in particular on legal and ethical concerns, and also concerning general aspects of health (Hall, 2013).

Medical tourism can take place within a patient's country or region of residence (Hudson, \& Li, 2012; Lubowiecki-Vikuk, \& Bosiacki, 2012; Todd, 2012, pp. 114-115) or in neighboring countries and/or other countries (Yeoh et al., 2013; Lunt et al., 2014), including those on other continents. The main medical tourism destinations are countries in Central and Eastern Europe (including Hungary, Poland, the Czech Republic, Slovakia, Belgium, France, and Germany), Asia (especially India, Thailand, and Malaysia /Uemura, 2012/), South America, and the Middle East.

Medical tourism is a fairly complex process (Runnels, \& Carrera, 2012) resulting from the demands of the modern market, particularly the demand side. Undoubtedly, the high cost of healthcare in developed countries combined with the low prices of healthcare services in some developing countries is the main factor leading to the development of medical tourism (Andrei et al., 2014). Patients who purchase services in the field of medical tourism are driven by different motives. 
The research by Wongkit, and McKercher (2013, p. 10) suggests that apart from the cost of treatment, there are other factors. These include the following:

1. Quality of care of the medical service provider and its staff;

2. Qualification of physicians;

3. Quality of available medical treatments;

4. Quality of doctors and medical facilities of hospitals/ clinics;

5. Quality of required treatment (the best place to receive it);

6. Reputation of a medical service provider at the international level;

7. Availability of a required treatment;

8. Reputation of country as a hub of medical treatment providers;

9. Confidentiality;

10. International accreditation;

11. Supplementary services provided by a medical service provider;

12. Availability of follow-up services;

13. Privacy of treatment;

14. Availability of healthcare professionals that are fluent in a certain language;

15. Recommendations from family and friends;

16. Testimonials and other experiences, including comments from other patients;

17. Time/ avoidance of long waiting periods at home;

18. Favorable previous experiences with a medical service provider;

19. Language barrier;

20. Recommendations from others (including social networks or blogs);

21. Insurance coverage;

22. Recommendations from a personal doctor;

23. Recommendations from a specialist tour operator/ travel agent.

The analysis of Andrei et al., (2014) revealed the existence of other factors that determine the supply and demand in medical tourism: the patient's health insurance does not adequately cover a range of conditions or treatments, the patient needs to preserve the confidentiality of medical treatments, population ageing, investment in the development of health centers, and necessary infrastructure.

The medical tourist is frequently accompanied by a family member or friend (Yeoh et al., 2013; Holliday et al., 2015). These individuals directly influence patient decisions related to medical tourism procedures (Yeoh et al., 2013), take the role of (an informal) guardian, or even, in the case of a longer stay, become initiators of tourist activities (Casey et al., 2013; Holliday et al., 2015). They may also provide assistance in choosing formal or informal networks of providers of medical tourism services (Hanefeld et al., 2015).

Tourist trips taken for medical reasons have become an interesting economic and socio-cultural phenomenon. Undoubtedly, a patient (medical tourist), alternatively called a "medical traveler", "a traveler of medical values", or "a traveler of global healthcare" (Corman, \& Baloglu, 2011), plays a vital role in the medical tourism market. In the literature, there are few works devoted to the problems of this category of people (Wongkit, \& McKercher, 2013; Yeoh et al., 2013; Lunt et al., 2014). Other studies are rather vague sketchy and do not present the full, socio-demographic profile. The very determination of the number of medical tourists still remains a rough estimate. This is the reason why it is difficult to determine who medical tourists are. Lunt, and Carrera (2010) rightly pointed out that it is necessary to solve the problem of their identity and determine whether they perceive themselves as consumers, (mobile) patients, clients, tourists, or medical tourists. Because these people acquire medical services in private healthcare facilities, they are referred to as consumers, and, due to the cross-border healthcare in the EU, as (mobile) patients (Lunt et al., 2014). However, it is crucial that we not only recognize the motives for medical tourism, but also that we attempt to identify the experience and behaviors of medical tourists (Alsharif et al., 2010; Eissler, \& Casken, 2013), especially after their return to their place of residence. In this regard, scientific reports by Wongkit, and McKercher (2013) prove helpful. Combining the purpose of a trip with how it was decided upon, they 
delineated four segments of medical tourists in Thailand: the dedicated medical tourist, the holidaying medical tourist, the hesitant medical tourist, and the opportunistic medical tourist (Table 1). Wongkit, and McKercher's (2013) study of the satisfaction and dissatisfaction of medical tourists in India constitutes a supplement to the abovementioned typology. It recognizes that:
"the importance of the medical tourism segmenting customers, based on the type of medical care, required curative medicine or preventive medicine” (George et al., 2010, p. 16).

In their own studies, Yeoh et al., (2013) add that almost every medical tourist that has consumed medical services in Malaysia has "brought" another new medical tourist into Malaysia. The research of Wongkit, and McKercher (2013) could provide a starting point in segmenting the medical tourism market.

Table 1. Typology of medical tourists - case study of Thailand

\begin{tabular}{|c|c|c|c|c|c|c|}
\hline & $\begin{array}{l}\text { Medical } \\
\text { tourist } \\
\text { behaviors }\end{array}$ & $\begin{array}{l}\text { Decision } \\
\text { horizon }\end{array}$ & $\begin{array}{l}\text { Trip } \\
\text { purpose }\end{array}$ & $\begin{array}{l}\text { Characteristics } \\
\text { of medical tourist }\end{array}$ & $\begin{array}{l}\text { Most common } \\
\text { treatments }\end{array}$ & $\begin{array}{l}\text { Main reasons } \\
\text { for choosing a } \\
\text { treatment abroad }\end{array}$ \\
\hline \multicolumn{7}{|l|}{$\begin{array}{l}\text { Medical } \\
\text { tourist } \\
\text { type }\end{array}$} \\
\hline $\begin{array}{l}\text { Dedicated } \\
\text { medical } \\
\text { tourist }\end{array}$ & & $\begin{array}{l}\text { pre-plan } \\
\text { treatment }\end{array}$ & $\begin{array}{l}\text { medical } \\
\text { (equal to } \\
\text { exclusively } \\
\text { for } \\
\text { treatment) }\end{array}$ & $\begin{array}{l}\text { Someone who has } \\
\text { made the decision to } \\
\text { seek treatment prior } \\
\text { to departure and who } \\
\text { has also identified } \\
\text { seeking treatment as } \\
\text { the main reason, or as } \\
\text { equally important a } \\
\text { reason as a holiday } \\
\text { for pleasure, for their } \\
\text { travel decision. }\end{array}$ & $\begin{array}{l}\text { - plastic or } \\
\text { cosmetic surgery } \\
\text { (alone or with } \\
\text { other treatments) } \\
\text { - dental treatment } \\
\text { only } \\
\text { - invasive surgery } \\
\text { (alone or with } \\
\text { other treatments) }\end{array}$ & $\begin{array}{l}\text { - "to receive } \\
\text { medical treatment" } \\
\text { - to explore new } \\
\text { places and cultures, } \\
\& \text { "to receive } \\
\text { medical treatment" }\end{array}$ \\
\hline $\begin{array}{l}\text { Holiday- } \\
\text { ing } \\
\text { medical } \\
\text { tourist }\end{array}$ & & $\begin{array}{l}\text { pre-plan } \\
\text { treatment }\end{array}$ & $\begin{array}{l}\text { pleasure } \\
\text { trip } \\
\text { (mostly to } \\
\text { exclusively } \\
\text { for } \\
\text { treatment) }\end{array}$ & $\begin{array}{l}\text { Someone who has } \\
\text { identified a vacation } \\
\text { as the main reason to } \\
\text { travel and also pre- } \\
\text { planned to undergo } \\
\text { treatment at their } \\
\text { destination. }\end{array}$ & $\begin{array}{l}\text { - dental treatment } \\
\text { only } \\
\text { - eye care (alone } \\
\text { or with other } \\
\text { treatments) } \\
\text { - check-ups (alone } \\
\text { or with dental } \\
\text { care) }\end{array}$ & $\begin{array}{l}\text { - to visit friends } \\
\text { and relatives } \\
\text { (VFR), \& "to } \\
\text { receive medical } \\
\text { treatment" } \\
\text { - to fulfill a dream, } \\
\text { \& "to receive } \\
\text { medical treatment" } \\
\text { (as a secondary } \\
\text { activity) }\end{array}$ \\
\hline $\begin{array}{l}\text { Hesitant } \\
\text { medical } \\
\text { tourist }\end{array}$ & & $\begin{array}{l}\text { decision } \\
\text { after } \\
\text { arrival }\end{array}$ & $\begin{array}{l}\text { medical } \\
\text { (equal to } \\
\text { exclusively } \\
\text { for } \\
\text { treatment) }\end{array}$ & $\begin{array}{l}\text { Someone who has } \\
\text { probably considered } \\
\text { treatment prior to } \\
\text { departure, but who } \\
\text { did not make the final } \\
\text { decision until after } \\
\text { arrival. }\end{array}$ & $\begin{array}{l}\text { - dermatology } \\
\text { (alone or with } \\
\text { other treatments) } \\
\text { - check-ups (alone } \\
\text { or with dental } \\
\text { care) } \\
\text { - plastic or } \\
\text { cosmetic surgery } \\
\text { (alone or with } \\
\text { other treatments) }\end{array}$ & $\begin{array}{l}\text { - reasons other than } \\
\text { "to receive medical } \\
\text { treatment" } \\
\text { - to visit } \\
\text { friends, \&relatives } \\
\text { (VFR), \& "to } \\
\text { receive medical } \\
\text { treatment" }\end{array}$ \\
\hline $\begin{array}{l}\text { Opportu- } \\
\text { nistic } \\
\text { medical } \\
\text { tourist }\end{array}$ & & $\begin{array}{l}\text { decision } \\
\text { after } \\
\text { arrival }\end{array}$ & $\begin{array}{l}\text { pleasure } \\
\text { trip } \\
\text { (mostly to } \\
\text { exclusively } \\
\text { for } \\
\text { treatment) }\end{array}$ & $\begin{array}{l}\text { Someone who has } \\
\text { traveled to the } \\
\text { country primarily or } \\
\text { mainly for a holiday } \\
\text { and only decided to } \\
\text { seek treatment once } \\
\text { at the destination. }\end{array}$ & $\begin{array}{l}\text { - dental treatment } \\
\text { only } \\
\text { - check-ups (alone } \\
\text { or with dental } \\
\text { care) } \\
\text { - dermatology } \\
\text { (alone or with } \\
\text { other treatments) }\end{array}$ & $\begin{array}{l}\text { - reasons other than } \\
\text { "to receive medical } \\
\text { treatment" } \\
\text { - to fulfill a dream, } \\
\text { \& "to receive } \\
\text { medical treatment" } \\
\text { (as a secondary } \\
\text { activity) }\end{array}$ \\
\hline
\end{tabular}

Source: own study based on Wongkit, \& McKercher (2013, pp. 7-9). 


\section{Categories of medical tourism tourism in the context of physical culture}

In the search for the origins of tourism, the phenomenon of modern times, Osiński (2011) saw not only people's desire to learn about new cultures and customs of other people, but, among other things, the need for active recreation and a desire to satisfy their need for physical activity. In particular, participation in qualified, specialized active tourism enables the fulfillment of the abovementioned needs. The contemporary (usually sedentary) lifestyle often leads to the negligence of health and the physical condition (Biernat, \& Piątkowska, 2014).

Thus, tourist activities provide an opportunity for displaying pro-health behaviors that rarely or never occur in everyday life in a person's place of residence. Numerous benefits can be derived from participation in various forms of active tourism and leisure recreation. The most important of these include the improvement of physical fitness and overall capacity of the human body, as well as better mental well-being.

Given the above, there is a dilemma with the undisputed classification of medical tourism and its categories among forms of tourism that are clearly related to

"shaping prosomatic attitudes, developing various elements of physical fitness and showing the importance of preserving healthy hygiene habits" (Osiński, 2011, p. 97).

It seems that if a large number of medical tourists combine the purpose of their travels with other activities, such as a visit to relatives or friends, or general leisure activities, then they are likely to take up activities concerning sports and recreation as well. Moreover, according to Smith, and Puczko (2013), medical tourism and wellness tourism have a common ground in the form of medical wellness tourism called "medical spa" or "medi spa" tourism. Its purpose is therapeutic recreation, rehabilitation (lifestyle-related), and occupational wellness. Furthermore, it encompasses thalassotherapy and nutritional and detox programs.

There are categories of medical tourism, such as specialized medicine tourism (trips in which services in the fields of ophthalmology, orthopedics, urology, gynecology and obstetrics, dermatology, cardiology, diagnostics, and prevention are consumed; it is possible to connect this category of tourism with services in the field of invasive and minimally invasive surgery) and oncology tourism (relaxing trips that allow patients to recover from the negative effects of fighting cancer through their active participation in the rehabilitation process), which focus on participants' health and the regeneration of their mental and physical strength (Lubowiecki-Vikuk, 2015). However, the specificity of these trips do not allow participants to focus on real physical exercise during their trips. A thesis can thus be put forward that patients' participation in various categories of medical tourism contribute to the increasing overall concern about health and physical fitness. The issue requires broader research on medical tourism dependencies in the context of the values and elements of physical culture.

\section{Specialized tourism medicine: Liposuction versus physical activity}

The level of physical activity among Poles is varied and unsatisfactory. At the same time, due to scientists' adoption of numerous scientific research methods, it is difficult to accurately estimate the level of physical activity among Poles (Kantanista, \& Osiński, 2014). According to the Eurobarometer survey on sports and physical activity, 59\% of EU citizens never or hardly ever do any physical exercise or sports, and more than half of Poles (52\%) never do any sports (European Commission, 2014). Given the above, it may be assumed that leisure time activity oriented towards physical activity is very slowly becoming inscribed in Poles' habits and traditions.

The occurrence of diseases, including obesity, is the result of hypodynamia. The obesity epidemic occurs in societies of many economically developed and developing countries (Mascie-Taylor, \& Goto, 2007), resulting in a detrimental impact on human health and national healthcare systems (Zohrabian, 2005; Żakiewicz-Sobczak et al., 2014). It is acknowledged that obese people have a higher risk of developing various diseases, including cardiovascular diseases, high blood pressure, type II diabetes, atherosclerosis, gastrointestinal diseases, cancer, mental disorders, depression, and eating disorders (Żakiewicz-Sobczak 
et al., 2014, p. 592). Intensified physical activity constitutes one of the many ways to combat obesity. Even in health resorts, low levels of physical activity among both obese and slim patients have been noted (Chojnowski et al., 2013). Thus, it has been confirmed that obese people are characterized by generally low physical activity compared to slim individuals (Chojnowski et al., 2013). As is widely known,

"dietary restriction combined with endurance exercise training represents an effective strategy that promotes weight loss and reduces fat mass in obese people" (Hansen et al., 2007).

Nowadays, a significant interest in the fields of medicine that aim to eliminate the effects of aging and improve physical appearance and body shape can be observed. Obesity, which in many cultures used to be an ideal of beauty, is now perceived as negative; being thin is considered a symbol of health and good physical condition and is even a prerequisite for career success in some social groups (Sobańska, \& Głuszek, 2010, p. 7). Pawłucki (2013, p. 44) notes that "the body shape ideal changes seasonally and - depending on the fashion - modifies the steps of body shaping patterns (habilitative /creative/, recreative and rehabilitative)".

In the era of globalization, cosmetic surgery is becoming increasingly popular in society. While older men pay more attention to their bodily functions and the experience of old age than their own appearance (Liechty et al., 2014), older women still consider maintaining their appearance to be a priority (Liechty, 2012). Thus, men and women (at different ages) undergo various treatments, among which liposuction is one of the most popular (Benatti et al., 2012; Khanna, \& Filobbos, 2013); it remains the most common surgical procedure for obesity.

\section{Lipotourism: Active leisure tourism?}

Liposuction is a procedure that patients often undergo in commercial medical institutions located outside of their permanent place of residence. It becomes the main purpose of their trip. British people, who willingly come to Poland to undergo surgery due to the lower costs of the operation (Lunt et al., 2014), provide a good illustration of this activity. In the literature, the term "lipotourism" has been coined to describe this category of medical tourism (Furuya et al., 2008; Bax et al., 2014; Lubowiecki-Vikuk, 2015; Schlarb et al., 2015; Zosso et al., 2015).

Liposuction, also known as lipoplasty, liposculpture, and suction-assisted lipectomy, is a surgical procedure used to remove subcutaneous fat from many different sites on the human body by using a suction vacuum. It improves body contours and proportions, and ultimately enhances an individual's self-image (Enhancing your appearance..., 2008; Alam, \& Kaminer, 2010; Kiciak, 2010; Fraterrigo et al., 2014, p. 433). The procedure is most commonly performed on the buttocks, hips, thighs, abdomen, and other areas that may not have responded to diet and exercise.

This procedure involves the removal of fat through suction via a cannula (plastic tube). Liposuction methods can be divided according to amount of fluid removed and the mechanisms of the cannula. Many different types of liposuction procedures are currently performed: suction-assisted liposuction, ultrasoundassisted liposuction, power-assisted liposuction, twin-cannula (assisted) liposuction, external ultrasoundassisted liposuction, water-assisted liposuction, laser-assisted liposuction, SAFELipo, liposuction using the tumescent technique, and liposuction using sutures. They were described characterized by Alam, and Kaminer (2010), and Fraterrigo et al., (2014, pp. 433-434).

The amount and distribution of body fat differs between men and women. The research by Suder and Sokołowski (2014, p. 215) concludes that the:

"distribution of adipose tissue can be modified by particular elements of lifestyle such as: smoking too many cigarettes, prevalence of obesity in the family, lack of sports activity in the past, no physical activity during leisure time and low level of motor fitness" (Suder, \& Sokołowski, 2014, p. 215). 
The number and size of adipocytes in the subcutaneous tissue are higher in women than in men, and thus the percentage of fat in relation to total weight is greater in women (Siemińska, 2007, pp. 335-336). Liposuction is most commonly performed on the abdomen and thighs in women or the abdomen and flanks in men. Shridgarani et al., (2014) argue that liposuction helps in the treatment of men and women who do not suffer from obesity.

Khanna, and Filobbos (2013) note that the issue of whether liposuction is a contributing factor to weight loss is controversial. It should be clearly noted that in the context of the fundamental values of physical education, liposuction should not be considered an alternative to regular physical activity and dieting, and definitely should not be considered a method to combat obesity or metabolic disorders (Alam, \& Kaminer, 2010). Liposuction should only be considered a method of body contouring (Alam, \& Kaminer, 2010; Sobańska, \& Głuszek, 2010, p. 8). It is a recommended cosmetic treatment for those who wish to remove fat from body parts which resist conventional methods like diet and exercise (Kiciak, 2010, p. 414). An ideal candidate for liposuction would have a stable weight within the normal BMI range, would exercise regularly, and would have localized deposits of stubborn fat (Khanna \& Filobbos, 2013).

Liposuction has its advantages and disadvantages. In the case of healthy, obese women, a significant reduction in fasting plasma insulin resulting from large-volume liposuction has been reported (Boriani et al., 2014), while in women with normal weights, liposuction downregulates adiponectin subcutaneous adipose tissue (scAT) gene expression and serum levels and upregulates scAT gene expression of inflammation-related genes six months after surgery, irrespective of exercise training (Yazigi Solis et al., 2014). In addition, it has been suggested that using liposuction in the overall treatment of obesity could lead to an improvement in insulin sensitivity and thus greatly improve an obese patient's quality of life (Perez, 2007). However, "abdominal liposuction does not significantly improve obesity-associated metabolic abnormalities" (Klein et al., 2004). In turn, the research by Podgórska et al., (2011, p. 275) suggests that the combination of liposuction with subsequent compression therapy allows for a reduction in limb circumference by $3.5 \mathrm{~cm}$, improving physical fitness and resulting in a positive cosmetic effect. One liposuction technique, laser lipolysis, proves to be effective and accurate in removing excess fat and correcting local tissue laxity. Following this treatment, patients return to their daily activities in a very short time and achieve a very good cosmetic outcome (Sobańska, \& Głuszek, 2010). Methods of fat reduction using ultrasound, such as ultrasonic liposuction and ultrasonic cavitation, are now believed to be less invasive and highly effective treatments (Bandachowicz, 2013).

In the wide-ranging discussion of the advantages of liposuction (Rapprich et al., 2012), there are also opinions voiced by its opponents. Especially in the case of medical tourists who have undergone liposuction in economically developing countries, there have been reported cases of skin and soft tissue infections, wounds, and other surgical complications (Furuya et al., 2008; Khanna, \& Filobbos, 2013; Bax et al., 2014; Constantine et al., 2014; Nelson, 2014; Zosso et al., 2015). Patients have reported that the blood vessels and nerves in their skin have been damaged by surgery. Patients after surgery have part of skin blood vessels and nerves damaged. Due to the long period of regeneration of the skin trophic innervation, some of these changes may persist for a long time, even to the end of life (Kiciak, 2010). These patients, as Melendez, and Alizadeh have claimed (2011), may be a burden on national healthcare systems. Furthermore, some treatments may lead to a patient's death, as in the case of some patients who have undergone plastic or bariatric surgery (Turner, 2012). Medical tourists who are particularly at risk of dying after liposuction are those who receive limited postoperative care in the place of their permanent residence, or do not receive any postoperative care at all. Khanna, and Filobbos (2013) draw attention to the inadequate postoperative monitoring of patients who undergo large-volume fat removal. In addition, the reception place (destination) of medical tourism plays an important role in patients' risk-taking. Thailand and India, which are the leaders in the global market for medical tourism, are endemic regions, especially for patients from Europe and the Americas. As a consequence, they can put others at risk of infections that cannot be treated with standard treatments, and thus constitute a serious threat to public health (Crooks et al., 2013). 
It is surmised that an immediate decrease in body fat, regardless of the technique used, may affect body composition and the metabolic profile by triggering feedback mechanisms to regain body fat. Research by Hernandez et al., (2011) clearly shows that in women who had fat removed from their thighs, the fat accumulated again after a year in other parts of the body - mainly the abdomen, back, or shoulders. Meanwhile, it has been proven:

"that a small volume abdominal liposuction did not induce the regrowth of the aspirated fat but instead triggered a compensatory increase of visceral fat 6 months after surgery, which is effectively counteracted by physical activity. Importantly, a 4-month, supervised exercise program prevented this compensatory visceral fat increase, increased fat-free mass, and improved physical capacity and insulin sensitivity" (Benatti et al., 2012).

Nonetheless, the assumption of Fraterrigo et al., (2014, p. 438) should be agreed with, and hope should be expressed that:

"liposuction can potentially have real benefits in obese patients by improving physical appearance, clothing choices, and self-confidence and by making it easier to engage in regular physical activity and programmed exercise" (Fraterrigo et al., 2014, p. 438).

\section{The Lipotourist: A case study}

As a result of a direct interview that the author conducted with two patients that underwent liposuction, a profile of the "lipotourist" may be outlined. Although it is not complete, it may serve as a starting point for compiling a profile of medical tourists in the context of the aforementioned typologies of medical tourists.

Case 1: Sophie, aged 56:

"I went to the seaside for the treatment. My friend recommended a clinic and a doctor specialist. I went there alone three days early. Although it was not easy, I wanted to relax on the beach. My mind was occupied with thoughts about surgery all the time. In spite of that, I walked, even tried nordic walking, and went sightseeing. Along with liposuction, I underwent abdominoplasty. After two days, still in pain, I returned home. After a week and a half I was back in the hospital because I got an infection. It was a pretty unpleasant experience. Now it is all fine. My body shape has improved, and my mood lifted. Unfortunately, I love sweets and bake a lot of cakes. That is why I have gained weight. I have to think of some exercise routine because I will not go for the second liposuction".

Case 2: Adam, aged 34:

"I've tried everything, exercise, diet - but I could not get rid of belly fat. Indeed, I am not very keen on sports, but I forced myself. The results were poor. On various internet forums, I read about abdominal liposuction. I opted for the surgery and I arranged an appointment in the clinic in Wrocław. I have family there, so I stayed with them and had a chance to catch up with "family" matters - because of the distance $(420 \mathrm{~km})$, we rarely see each other. Although I did not avoid pain, the treatment was successful. Today I feel great. I would recommend it to anyone, although it can not be disregarded that in order to maintain the effect, you need to move. The doctor recommends physical activity. I confess that I do not do it on a regular basis, but I stick to a diet. However, from time to time, I indulge myself in food that is not particularly healthy". 


\section{Summary and directions for further research}

The scientific research findings and information from the field of medical tourism presented in this study make it possible to conclude that this form of health tourism develops very dynamically. In particular, the phenomenon of medical tourism is analyzed in economic terms that apply to both the demand side, taking into account the needs, experience, and behavior of consumers, as well as the supply side, focusing on the necessary materials, technical conditions, and organization in order to maximize the profits of commercial entities. It has been acknowledged that the concept of medical tourism is complex, as is evidenced by the categories which have been pointed out in this study. This state of affairs can and in fact does cause controversies of a socio-cultural, religious, legal, economic, (bio)ethical, and moral nature.

Given the aforementioned findings, it is interesting from a scientific point of view whether a participant of modern health tourism, specifically of medical tourism, cares about his/ her health, and if so, in what way he/ she maintains health. The passive lifestyle and consumer habits of society (including the acquisition of aesthetic medical services and travel services) seem to suggest that the value of health and general body fitness is decreasing in society. However, this argument requires empirical evidence. Thus, the study refers to the particular case of liposuction treatments and the travel of individuals whose direct or indirect objective is to undergo liposuction (lipotourism). Benatti et al., (2012, p. 2389) claims that "it is plausible that the effects of liposuction may be highly impacted by physical activity levels after the surgical procedure".

Physical culture sciences do not provide any empirical evidence which could indicate or at least allow for the estimation of the level and evaluation of the quality and structure of the physical activity of patients after liposuction. The two cases studies of individuals who participated in lipotourism indicate a mediocre outcome. Underestimating the importance of physical activity both before and after liposuction treatment usually in their spare time can cause various and immeasurable losses. It seems that the motivations for undergoing liposuction treatments and their health and socio-cultural consequences may become a key element in creating a model of behavior describing the norms, values, needs, and aspirations of the growing number of consumers of this type. In view of the submitted presumptions, it seems to be of significant importance for both practical and cognitive reasons that comprehensive research be conducted in the field of the physical culture of patients after liposuction.

A clear answer to the question posed in the title of the study - "Participation in medical tourism versus physical activity of patients after liposuction: What are the concerns about health and quality of life?" - still remains a matter of investigation and numerous deductions. Participating in tourism for medical reasons can affect the "degree of perfection" of life, but with certain assumptions, i.e.:

1. The applied treatment does not cause (permanent) damage to the patient's health;

2. Liposuction will be treated exclusively as an (invasive) aesthetic surgery and not as a method of weight reduction;

3. Regular physical activity and a healthy diet and lifestyle will be included in the process of body shaping, and;

4. Health and physical education will be treated as superior values of quality of life. The existing considerations should only be regarded as preliminary.

\section{REFERENCES}

Alam, M., \& Kaminer, M.S. (2010). Liposuction. In B.E. Katz, \& N.S. Sadick (Eds.), Body Contouring. Procedures in Cosmetic Dermatology (pp. 69-96). London: Saunders Elsevier.

Alsharif, M.J., Labonte, R., \& Lu, Z. (2010). Patients beyond borders: a study of medical tourists in four countries. Global Social Policy, 10(3), 315-335. DOI: 10.1177/1468018110380003. 
Andrei, C.L., Ţigu, G., Drăgoescu, R.M., \& Sinescu, C.J. (2014). Analysis of Medical Tourism for Cardiovascular Diseases. Amfiteatru Economic, 16(8), 1136-1150.

Bandachowicz, D. (2013). Zastosowanie ultradźwięków w redukcji tkanki tłuszczowej /The use of ultrasound to reduce body fat /. Polish Journal of Cosmetology, 16(3), 186-189.

Bax, H.I., van Ingen, J., Dwarkasing, R.S., \& Verbon, A. (2014). Lipotourism, not without risks: a complication of cosmetic surgery abroad. Nederlands Tijdschrift voor Geneeskunde, 158, A7926.

Benatti, F., Solis, M., Artioli, G., Montag, E., Painelli, V., Saito, F., \& et al. (2012). Liposuction induces a compensatory increase of visceral fat which is effectively counteracted by physical activity: a randomized trial. Journal of Clinical Endocrinology \& Metabolism, 97(7), 2388-2395. DOI: 10.1210/jc.2012-1012.

Biernat, E., \& Piątkowska, M. (2014). Individual and Environmental Factors Determining Sedentary Lifestyle of the Polish Population. Iranian Journal of Public Health, 43(8), 1033-1044.

Boriani, F., Villani, R., \& Morselli, P.G. (2014). Metabolic effects of large-volume liposuction for obese healthy women: a meta-analysis of fasting insulin levels. Aesthetic Plastic Surgery, 38(5), 1050-1056.

Breitrück, V., \& Nunn, E. (2011). Health \& medical tourism. In A. Papathanassis (Ed.), The Long Tail of Tourism: Holiday Niches and their Impact on Mainstream Tourism (pp. 57-67). Wiesbaden: Gabler Verlag.

Cameron, K., Crooks, V.A., Chouinard, V., Snyder, J., Johnston, R., \& Casey, V. (2014). Motivation, justification, normalization: Talk strategies used by Canadian medical tourists regarding their choices to go abroad for hip and knee surgeries. Social Science \& Medicine, 106, 93-100.

Casey, V., Crooks, V.A., Snyder, J., \& Turner, L. (2013). Knowledge brokers, companions, and navigators: a qualitative examination of informal caregivers' roles in medical tourism. International Journal for Equity in Health, 12, 94.

Chojnowski, J., Tołodziecki, M., Adamczyk, P., Trawińska, M., \& Ponikowska, I. (2013). State of physical activity of patients treated in health resort conditions. Acta Balneologica, 55(1,131), 13-18.

Cohen, I.G. (2012). Circumvention tourism. Cornell Law Review, 97(6), 1309-1398.

Constantine, R.S., Davis, K.E., \& Kenkel, J.M. (2014). The effect of massive weight loss status, amount of weight loss, and method of weight loss on body contouring outcomes. Aesthetic Surgery Journal, 34(4), 578-583.

Cormany, D., \& Baloglu, S. (2011). Medical travel facilitator websites: An exploratory study of web page contents and services offered to the prospective medical tourist. Tourism Management, 32(4), 709-716.

Crooks, V.A., Turner, L., Cohen, I.G., Bristeir, J., Snyder, J., Casey, V., \& et al. (2013, February). Ethical and legal implications of the risks of medical tourism for patients: a qualitative study of Canadian health and safety representatives' perspectives. BMJ Open, 3, e002302. Retrieved February 3, 2015, from http://bmjopen.bmj.com/content/3/2/e002302.full; DOI: 10.1136/bmjopen-2012-002302.

Eissler, L.A., \& Casken, J. (2013). Seeking healthcare through international medical tourism. Journal of Nursing Scholarship, 45(2), 177-184.

Enhancing your appearance with liposuction (2008). A.J. Bulletin, 2, 17-20.

European Commission (2014). Special Eurobarometer 412. Sport and physical activity. Retrieved February 19, 2015, from http://ec.europa.eu/public_opinion/archives/ebs/ebs_412_en.pdf

Franzblau, L.E., \& Chung, K.C. (2013). Impact of medical tourism on cosmetic surgery in the United States. Plastic and Reconstructive Surgery. Global Open, 1(7), e63. DOI: 10.1097/GOX.0000000000000003.

Fraterrigo, G., Fontana, L., \& Klein, S. (2014). Liposuction and Obesity. In G.A. Bray \& C. Bouchard (Eds.), Handbook of Obesity (pp. 433-440). Boca Raton, FL: CRC Press Inc.

Freyer, W., \& Kim, B.S. (2014). Medizintourismus und Medizinreisen - eine inter-disziplinäre Betrachtung /Medical tourism and medical travels - an interdisciplinary approach /. Gesundheitswesen, 76(1), 65-68.

Furuya, E.Y., Paez, A., Srinivasan, A., Cooksey, R., Augenbraun, M., Baron, M., \& et al. (2008). Outbreak of Mycobacterium abscessus wound infections among "lipotourists" from the United States who underwent abdominoplasty in the Dominican Republic. Clinical Infectious Diseases, 46(8), 1181-1188.

George, B.P., Henthorne, T.L., \& Williams, A.J. (2010). Determinants of satisfaction and dissatisfaction among preventive and curative medical tourists: a comparative analysis. International Journal of Behavioural and Healthcare Research, 2(1), 5-19. 
Hall, C.M. (Ed.), (2013). Medical Tourism. The ethics, regulation, and marketing of health mobility. London: Routledge.

Hanefeld, J., Lunt, N., Smith, R., \& Horsfall, D. (2015). Why do medical tourists travel to where they do? The role of networks in determining medical travel. Social Science \& Medicine, 124, 356-363.

Hansen, D., Dendale, P., Berger, J., van Loon, L.J.C., \& Meeusen, R. (2007). The Effects of Exercise Training on FatMass Loss in Obese Patients During Energy Intake Restriction. Sports Medicine, 37(1), 31-46.

Hernandez, T.L., Kittelson, J.M., Law, C.K., Ketch, L.L., Stob, N.R., Lindstrom, R.C., \& et al. (2011). Fat Redistribution Following Suction Lipectomy: Defense of Body Fat and Patterns of Restoration. Obesity, 19(7), 1388-1395.

Holliday, R., Bell, D., Cheung, O., Jones, M., \& Probyn, E. (2015). Brief encounters: Assembling cosmetic surgery tourism. Social Science \& Medicine, 124, 298-304.

Hudson, S., \& Li, X. (2012). Domestic medical tourism: a neglected dimension of medical tourism research. Journal of Hospitality Marketing \& Management, 21(3), 227-246.

Kantanista, A., \& Osiński, W. (2014). Physical activity of Poles - Critical analysis of research 2010-2014. Annals of Agricultural and Environmental Medicine, 21(4), 839-843.

Khanna, A., \& Filobbos, G. (2013). Avoiding unfavourable outcomes in liposuction. Indian Journal of Plastic Surgery, 46(2), 393-400. DOI: 10.4103/0970-0358.118618.

Kiciak, A. (2010). Surgical approaches to aid and substitute weight loss. Kosmos. Problemy Nauk Biologicznych, 59(3-4), 413-419.

Klein, S., Fontana, L., Young. V.L., Coggan, A.R., Kilo, C., Patterson, B.W., \& et al. (2004). Absence of an effect of liposuction on insulin action and risk factors for coronary heart disease. The New England Journal of Medicine, 350(25), 2549-2557.

Kowalska, I., Sagan, A., Mokrzycka, A., \& Zabdyr-Jamróz, M. (2015). The first attempt to create a national strategy for reducing waiting times in Poland: Will it succeed? Health Policy, 119(3), 258-263. DOI: 10.1016/j.healthpol.2014.12.010.

Labonté, R. (2013). Medical Tourism Today: What, Who, Why and Where? In R. Labonté, V. Runnels, C. Packer \& R. Deonandan (Eds.), Travelling well: Essays in medical tourism (pp. 6-42). Ottawa, ON: University of Ottawa Press.

Liechty, T. (2012). "Yes, I worry about my weight... but for the most part I'm content with my body": Older Women's Body Dissatisfaction Alongside Contentment. Journal of Women \& Aging, 24(1), 70-88.

Liechty, T., Ribeiro, N.F., Sveinson, K., \& Dahlstrom, L. (2014). "It's about what I can do with my body": Body Image and Embodied Experiences of Aging among Canadian Men. International Journal of Men's Health, 13(1), 3-21.

Lubowiecki-Vikuk, A. (2010). Turystyka medyczna jako forma globalnej opieki zdrowotnej w kontekście rekreacyjnej aktywności fizycznej obywateli krajów Unii Europejskiej / Medical tourism as a form of global health in the context of recreational physical activity among citizens of the European Union/. In W. Siwiński, R.D. Tauber \& E. Mucha-Szajek (Eds.), Rozwój ustug turystyczno-rekreacyjnych $i$ hotelarsko-gastronomicznych $w$ warunkach globalizacji /The development of tourist-recreational services and hospitality catering in the conditions of globalization/ (pp. 185-191). Poznań: WSHiG, PSNARiT.

Lubowiecki-Vikuk, A. (2012a). Trends in the development of medical tourism in Poland. International Medical Travel Journal. Retrieved March 10, 2015, from http://www.imtj.com/articles/2012/medical-tourism-poland-30145/

Lubowiecki-Vikuk, A. (2012b). Turystyka medyczna przejawem współczesnych trendów i tendencji w turystyce / Medical tourism as a manifestation of contemporary trends and tendencies in tourism/. Zeszyty Naukowe Uniwersytetu Szczecińskiego. Ekonomiczne Problemy Ustug, 84, 553-568.

Lubowiecki-Vikuk, A. (2015). Specyficzność turystyki medycznej / Specificity of medical Tourism/. In G. Godlewski \& M. Zalech (Eds.), Turystyka kontrowersyjna na wspótczesnym rynku podróży - formy, uwarunkowania, skutki /Controversial tourism in today's travel market - forms, conditions, effects/ (pp. 163-172). Biała Podlaska: AWF.

Lubowiecki-Vikuk, A., \& Bosiacki, S. (2012). Możliwości rozwoju turystyki medycznej w Poznaniu w ujęciu podażowo-popytowym /Opportunities for development of medical tourism in Poznan in terms of supply-demand factors/. Turystyka i Rekreacja, 8, 41-53.

Lubowiecki-Vikuk, A., \& Mucha, D. (2015). Perspektywy rozwoju turystyki farmaceutycznej w regionie Polski południowej / Perspectives for the development of the pharmaceutical tourism in the region of southern Poland/. Rozprawy Naukowe Akademii Wychowania Fizycznego we Wrocławiu, 49, 147-156. 
Lubowiecki-Vikuk, A., \& Rab-Przybyłowicz, J. (2015). Wybrane aspekty funkcjonowania rynku turystyki medycznej w Polsce / Selected aspects of the functioning of the market of medical tourism in Poland/. Folia Turistica, 34, 85-107.

Lunt, N., \& Carrera, P. (2010). Medical tourism: Assessing the evidence on treatment abroad. Maturitas, 66(1), 27-32.

Lunt, N., Smith, R.D., Mannion, R., Green, S.T., Exworthy, M., Hanefeld, J., \& et al. (2014). Implications for the NHS of inward and outward medical tourism: a policy and economic analysis using literature review and mixed-methods approaches. Health Services and Delivery Research, 2(2), 1-234.

Mascie-Taylor, C.G.N., \& Goto, R. (2007). Human Variation and Body Mass Index: A Review of the Universality of BMI Cut-offs, Gender and Urban-rural Differences, and Secular Changes. Journal of Physiological Anthropology, 26(2), 109-112.

Matteelli, A., Carvalho, A.C., \& Bigoni, S. (2012). Visiting relatives and friends (VFR), pregnant, and other vulnerable travelers. Infectious Disease Clinics of North America, 26(3), 625-635.

Melendez, M.M., \& Alizadeh, K. (2011). Complications from international surgery tourism. Aesthetic Surgery Journal, 31(6), 694-697.

Nelson, R. (2014). Infectious risks of medical tourism. The Lancet, 14(8), 680-681.

Official Journal of the European Union (2011). Directive 2011/24/EU of the European Parliament and of the Council of 9 March 2011 on the application of patients' rights in cross-border healthcare, 50(88),45. 4 April 2011.

Osiński, W. (2011). Teoria wychowania fizycznego /Theory of physical education/. Poznań: AWF.

Pawłucki, A. (2013). Nauki o kulturze fizycznej /Physical Culture sciences/. Wrocław: AWF.

Perez, R.A. (2007). Liposuction and diabetes type 2 development risk reduction in the obese patient. Medical Hypotheses, 68(2), 393-396.

Podgórska, K., Drożdż, K., Bieniek, A., \& Szuba, A. (2011). Liposuction in the treatment of idiopathic lower extremity lymphoedema. Acta Angiologica, 17(4), 271-276.

Rapprich, S., Koller, J., Sattler, G., Wörle, B., Sommer, B., Bechara, F.G., \& et al. (2012). Liposuction - a surgical procedure in dermatology. Journal der Deutscheen Dermatologischen Gesellschaft, 10(2), 111-113.

Rasińska, R., \& Siwiński, W. (2014). Medical tourism - travels in search of health in the opinion of women aged 40-60. Rozprawy Naukowe Akademii Wychowania Fizycznego we Wroctawiu, 45, 146-152.

Reed, C.M. (2008). Medical tourism. The Medical Clinics of North America, 92(6), 1433-1446.

Runnels, V., \& Carrera, P.M. (2012). Why do patients engage in medical tourism? Maturitas, 73(4), 300-304.

Schlarb, D., Idelevich, E.A., Krause-Bergmann, A., \& Stollwerck, P. (2015). Successful interdisciplinary radical treatment of Mycobacterium fortuitum infection in a lipotourist from Germany after abdominoplasty in Turkey. New Microbes and New Infections, 8, 21-23. DOI: 10.1016/j.nmni.2015.09.003.

Shridharani, S.M., Broyles, J.M., \& Matarasso, A. (2014). Liposuction devices: technology update. Medical Devices (Auckland, N.Z.), 7, 241-251.

Siemińska, L. (2007). Adipose tissue. Pathophysiology, distribution, sex differences and the role in inflammation and cancerogenesis. Endokrynologia Polska, 58(4), 330-342.

Smith, M., \& Puczko, L. (2013). Health, Tourism and Hospitality: Spas, Wellness and Medical Travel. London: Rutledge Taylor \& Francis Group.

Sobańska, K., \& Głuszek, S. (2010). Select surgical and cosmetic procedures used in treating obesity and cellulite. Studia Medyczne /Medical Studies/, 19, 7-11.

Suder, A., \& Sokołowski, A. (2014). Relationship of Social and Lifestyle Factors with Central Fat Distribution Expressed by the Aggregate Fat Distribution Index. Anthropological Review, 77(2), 205-218.

Todd, M.K. (2012). Medical Tourism Facilitator’s Handbook. Boca Raton: CRC Press, Taylor \& Francis Group.

Turner, L. (2012). News media reports of patient deaths following 'medical tourism' for cosmetic surgery and bariatric surgery. Developing World Bioethics, 12(1), 21-34.

Uemura, K. (2012). Trends in medical tourism as healthcare goes global. Health Evaluation and Promotion, 39(6), 844-848.

Wongkit, M., \& McKercher, B. (2013). Toward a typology of medical tourists: A case study of Thailand. Tourism Management, 38, 4-12. 
Yazigi Solis, M., Artioli, G.G., Montag, E., Painelli, V.S., Saito, F.L., Lima, F.R., \& et al. (2014). The LiposuctionInduced Effects on Adiponectin and Selected Cytokines Are Not Affected by Exercise Training in Women. International Journal of Endocrinology, 2014, ID 315382. DOI: 10.1155/2014/315382.

Yeoh, E., Othman, K., \& Ahmad, H. (2013). Understanding medical tourists: Word-of-mouth and viral marketing as potent marketing tools. Tourism Management, 34, 196-201.

Zohrabian, A. (2005). The long-term effects and economic consequences of treatments for obesity: work in progress. The Lancet, 365(9454), 104-105.

Zosso, C., Lienhard, R., Siegrist, H.H., Malinverni, R., \& Clerc, O. (2015). Post liposuction infections by rapidly growing mycobacteria. Infectious Diseases (London, England), 47(2), 69-72.

Żukiewicz-Sobczak, W., Wróblewska, P., Zwoliński, J., Chmielewska-Badora, J., Adamczuk, P., Krasowska, E., \& et al. (2014). Obesity and poverty paradox in developed countries. Annals of Agricultural and Environmental Medicine, 21(3), 590-594.

AUTHOR'S ADDRESS: $\quad$ Adrian Lubowiecki-Vikuk Kazimierz Wielki University in Bydgoszcz

Faculty of Physical Education, Health and Tourism

Mińska 15

85-428 Bydgoszcz, Poland

E-mail: lubowiecki@ukw.edu.pl

Received: 8 July 2014; Accepted: 8 September 2014 